\title{
13 \\ Writing Home on the Pari and Touring in Pacific Studies
}

\author{
Jo Diamond
}

Editors' Note: Jo Diamond's paper presented at the Australian Association of Pacific Studies conference, Wollongong, Australia, April 2012, in our session 'Touring Pacific Cultures' was an extraordinary scholarly performance piece framed as a mystery tour. Textual content comprised a collection of notes to herself, postcards, exchanges with her dissertation supervisor, family and friends. This essay/performance is a pointed reminder of the many types of relations that make up the research and writing process as well as the pressing issues of cultural recognition and ownership, the ethics of cross-cultural curiosity and the politics of history and collecting.

Kia ora koutou, greetings everyone. Ko te mihi tuatahi, ko te mihi aroha mo o matou tupuna katoa I tua o te arai, takoto, takoto, takoto. ... I firstly acknowledge all those people, belonging to all of us, who have gone before us and without whom, we would not be here. This acknowledgement is in keeping with many cultural protocols of the world, including those associated with Māori people like me, who pay respects to ancestors.

Also in keeping with those protocols, I pay special tribute to tangata whenua-those living and deceased of this land where we have gathered now, no matter how temporarily. Nga mihi nunui ki te mana whenua, o te wahi nei, o te wa nei, o te po me te ao kikokiko hoki. Greetings to one and all! 
Dear fellow conference delegates,

I am a traveller, a visitor; yes even a tourist when I take direction from C. Michael Hall, a fellow University of Canterbury, New Zealand scholar and his colleagues who addressed fieldwork in tourism. ${ }^{1}$ He offers valuable insights regarding the following:

- variables afoot in tourism-based research such as positioning of the researcher and those being researched

- questions of the extent and paradigms of the so-called 'field' referred to by the term 'fieldwork'

- debates surrounding 'belonging' in amongst and quite apart from ethnographic foci

- and definitely not last or least, those vexed questions regarding cultural identity, performance and politics that sometimes seep in and at other times 'thump' with dramatic impact upon conceptual frameworks and elements of any kind of study, including definitions of 'touring' and 'tourism'.

These insights are valid, ongoing and helpful contributions for engagement with the very important notion or, more accurately, sets of notions surrounding touring in and of the/a Pacific region. The sets are the life-blood as, no matter how loosely or tightly they are interpreted as a 'field', they are invaluable to the advancement of Pacific Studies.

I have elected to create my contribution in somewhat l-i-t-e (borrowing from diet food labels) fashion. In doing so, I offer an engagement with the pari, a Māori bodice worn by cultural performance groups, that is not so based on a conventional or traditional model of an academic paper.

1 C. Michael Hall, 2011, 'Fieldwork in tourism/touring fields: Where does tourism end and fieldwork begin', in Fieldwork in Tourism: Methods, Issues and Reflections, ed. C. Michael Hall, pp. 7-18, Oxon, Routledge, p. 7ff. 
Instead, I offer postcard, diary entry, letter-home and email-like snippets associated with a set of images. Some of these snippets are 'posted' here to you as if I am away overseas, writing home to you. Others are records of correspondence I actually have had or would have had with others who are not here. I may tend towards vagueness or inadequate explanations with this style and do encourage your questions or comments during or following this reading.

Please use these two images as a Tour Introduction of a big wide world of enquiry, no less, which for me began in earnest some 14 years ago whilst researching for my $\mathrm{PhD} .^{2} \mathrm{~A}$ huge shout-out to my former fellow ANU instructors and students of that time, present here today. Images such as those in Figures 71 and 72 conjure in our minds stereotypical ideas about Māori culture. Tourist-attracting Māori women are glamorous, warm, welcoming and available, are they not? A veritable 'meal' they are, for discussing gender-related cultural identity and representation, including the staging with props of an ideal, attractive destination, ripe for the picking. Especially created for postcard, pamphlet, poster and coffee-table book viewing if not actual physical touring-don't you think? But, please do remember to focus on the bodice that each of these beautiful women is wearing. It is this pari that grabs hold of me (and, I assert, all of you) in the process of me telling some of its stories. Arohanui Jo

2 Jo Diamond, 2004, 'Revaluing Raranga: Weaving and women in trans-Tasman Māori cultural discourses', PhD thesis, The Australian National University. 


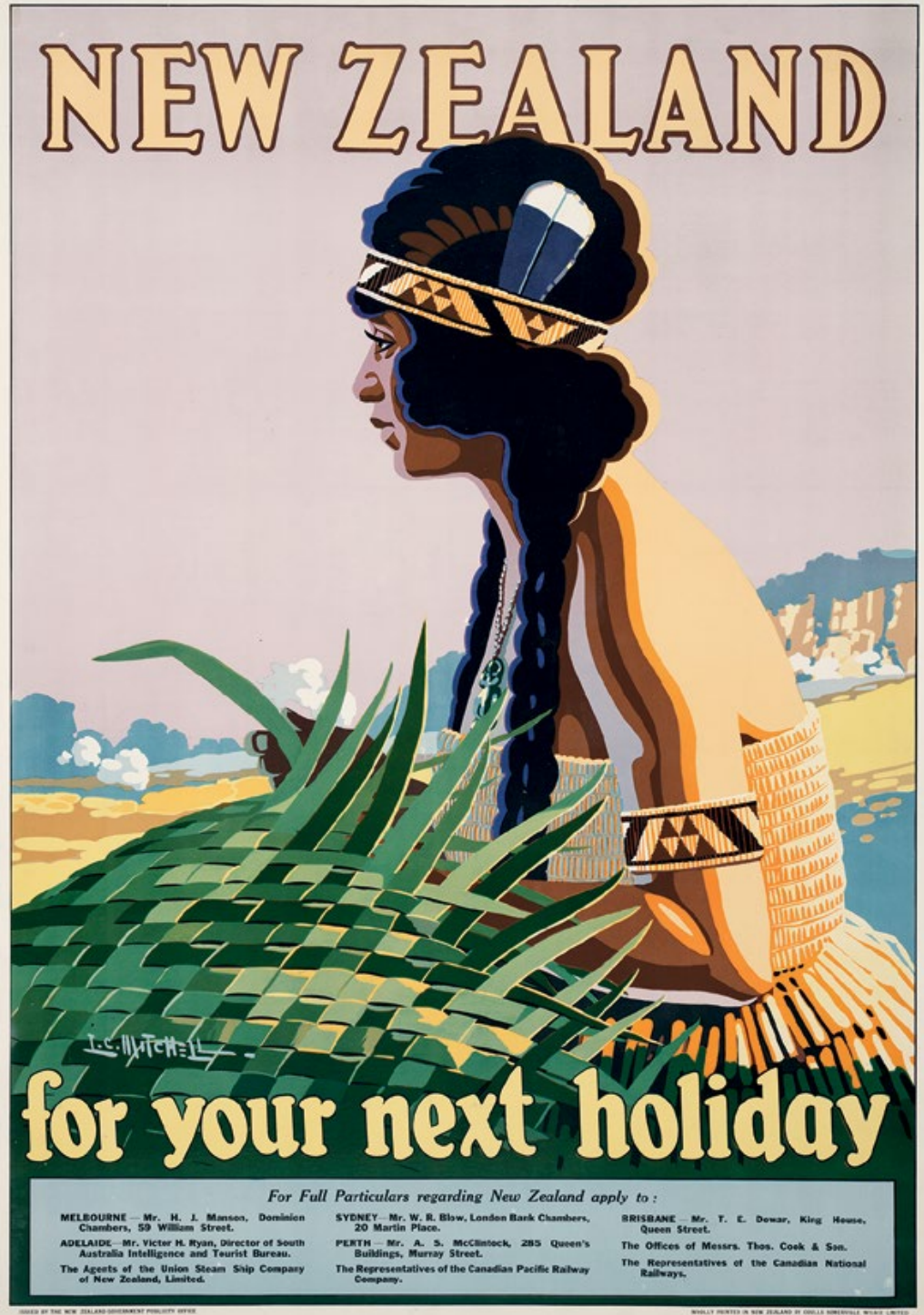

Figure 71. Image of the welcoming and available Māori women.

Source. Mitchell, Leonard Cornwall, 1901-1971. Mitchell, Leonard Cornwall, 1901-1971: New Zealand for your next holiday. Issued by the New Zealand Government Publicity Office. Wholly printed in New Zealand by Coulls Somerville Wilkie Limited, Dunedin, Christchurch, Wellington, Auckland [ca 1925-1929]. Ref: Eph-E-TOURISM-1920s-02. With permission, Alexander Turnbull Library, Wellington, New Zealand. Online: natlib.govt. nz/records/23188666 (accessed 23 May 2016). 


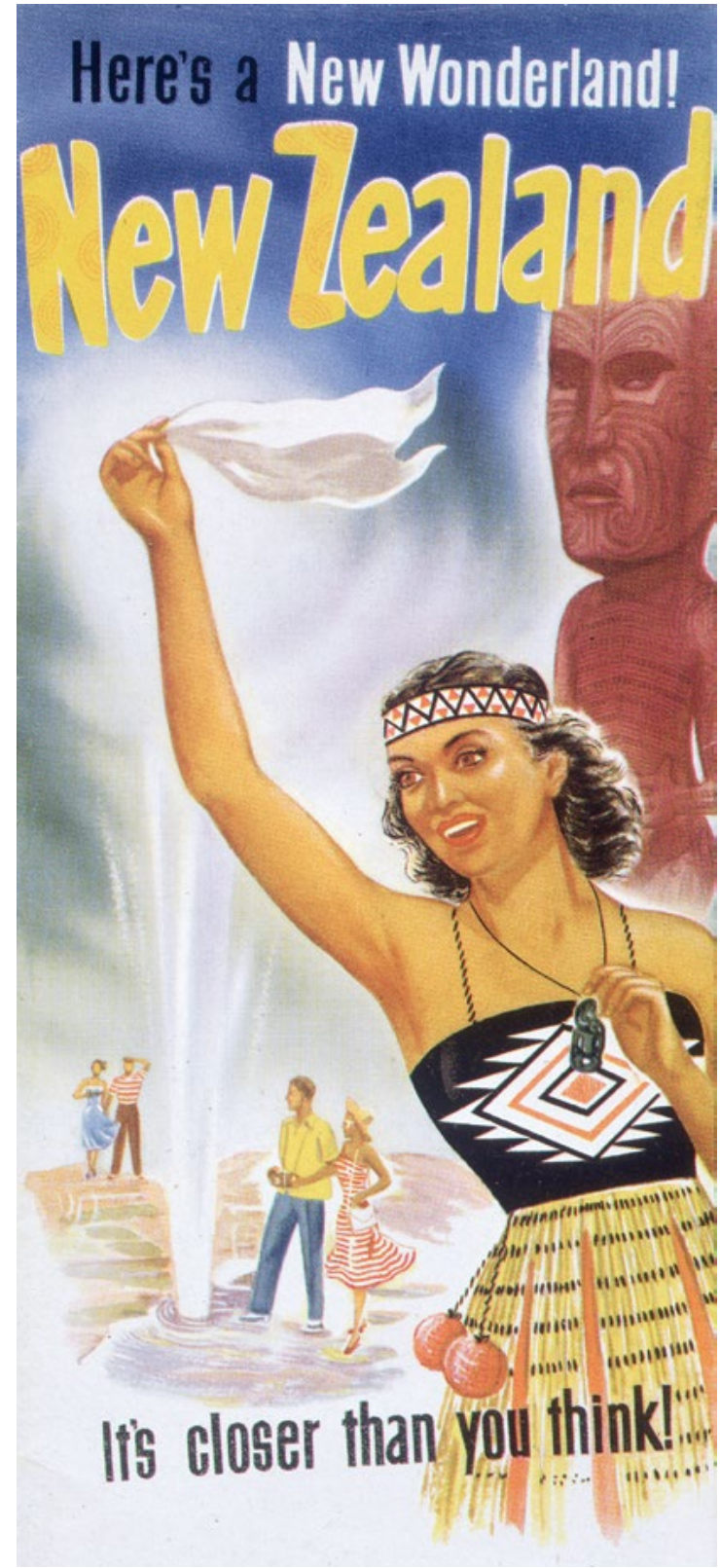

Figure 72. Image of the welcoming and available Māori women.

Source. New Zealand. Tourist and Publicity Department. New Zealand Tourist and Publicity Department: Here's a new wonderland! New Zealand. It's closer than you think! [1950s]. Ref: Eph-A-TOURISM-NZ-1950s-01. Alexander Turnbull Library, Wellington, New Zealand. With permission, Tourism New Zealand. Online: natlib.govt.nz/records/22863971 (accessed 23 May 2016). 


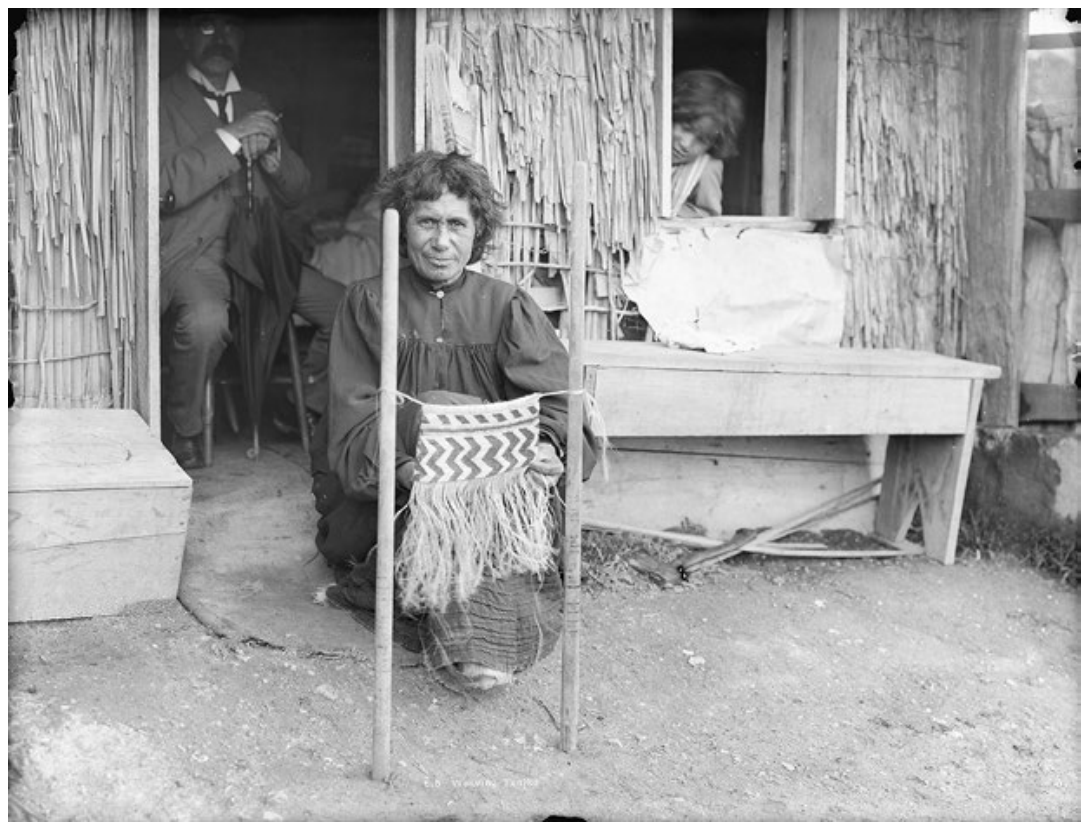

Figure 73. As yet unidentified Māori woman weaving in taniko method.

Source. Māori woman weaving taniko. Birch, A E: Scenic negatives and prints taken by Thomas Pringle. Ref: 1/1-007019-G. With permission, Alexander Turnbull Library, Wellington, New Zealand. Online: natlib.govt.nz/records/22630497 (accessed 23 May 2016).

Note to Sylvia (my PhD supervisor),

There's got to be a connection between pari and photographic records such as these readily available for purchase from the Alexander Turnbull Library. As yet unidentified women, some weaving and others wearing, all capturing the fascination of photographers in the late nineteenth - early twentieth centuries. Such images entice me into the enquiry based on a rapidly forming curiosity about how, why and when the pari emerged. It was not there in the nineteenth century. It is, as you know, very much here in the twenty-first century. I am writing at least one chapter about what could be called a micro-history of the pari, especially since very little engagement with its 100 or so years of its existence, has yet to meet a published page. Best regards as always, Jo 


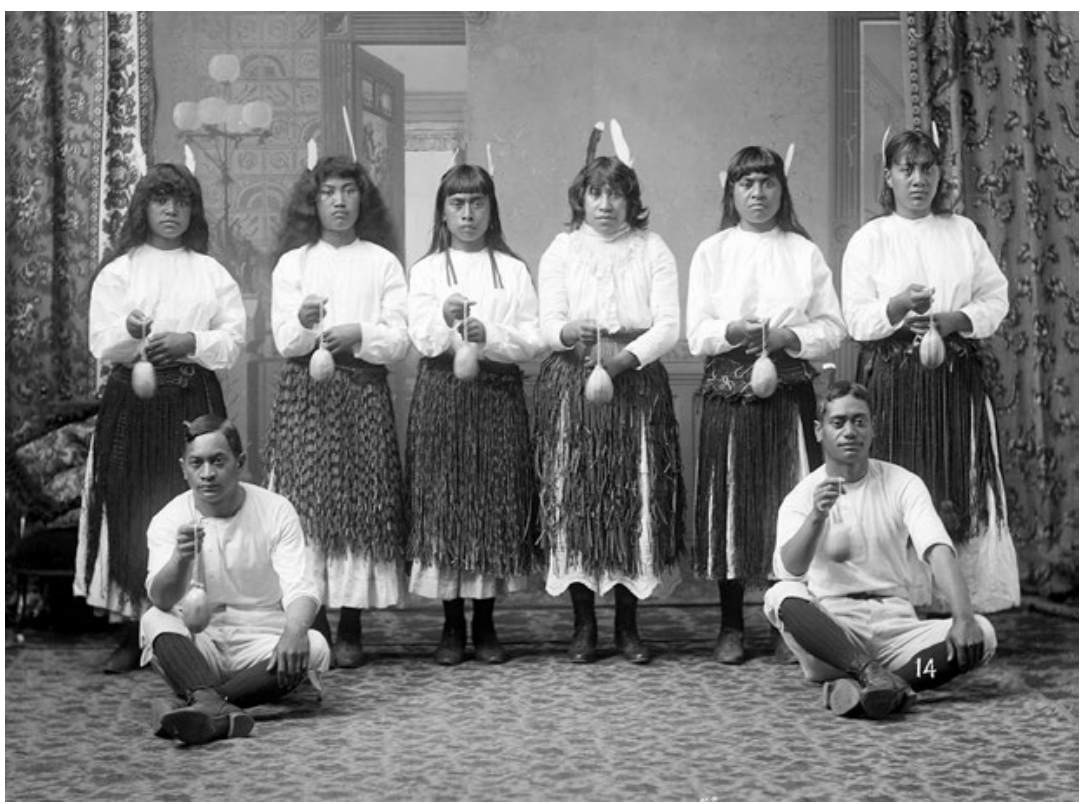

Figure 74. Unidentified Māori women with poi, piupiu and white dresses accompanied by two men.

Source. Group with poi at Putiki. Auckland Star: Negatives. Ref: 1/1-003145-G. With permission, Alexander Turnbull Library, Wellington, New Zealand. Online: natlib.govt.nz/ records/23087250 (accessed 23 May 2016).

\section{Quick note to self,}

White blouses, Victorian in character, poi and piupiu, not to mention feathers, say at least 2 things: Christianity had a role to play in the pari's forerunner for female cultural performers, replacing so-called 'native' dress or 'undress' with high-necked purity despite retaining some Māori trappings. A constrained cultural representation connoting the 'civilisation' of Māori performers into quaint poi-twirlers, women and men included, in starched white clothing. No sign here yet of the seductive pari that comes later. Perhaps this is a regionally based idea of moral appropriateness or religious conviction that whiteness is godliness; some fantasy based on civilising so-called savages. A precursor to the pari is this? Or, is it antithesis? Watch out for historicentric conclusions based on boiling (angry) blood in my veins. Softly, softly catchy pari. 
Dear Sue,

Thanks for your advice on ordering copies of images from the National Library collection. Thanks also for your interest in my topic for the book. I'll pick the images up on my way to Te Papa next week. I'm convinced that the pictures dated in the 1920s are an historical link that I am looking for, between the trend of the late nineteenth century of wearing cloaks and piupiu around the shoulders and torso, and the later performance 'costume' (not the best name for it) that we are familiar with nowadays. Until we meet on Wednesday, best regards, Jo

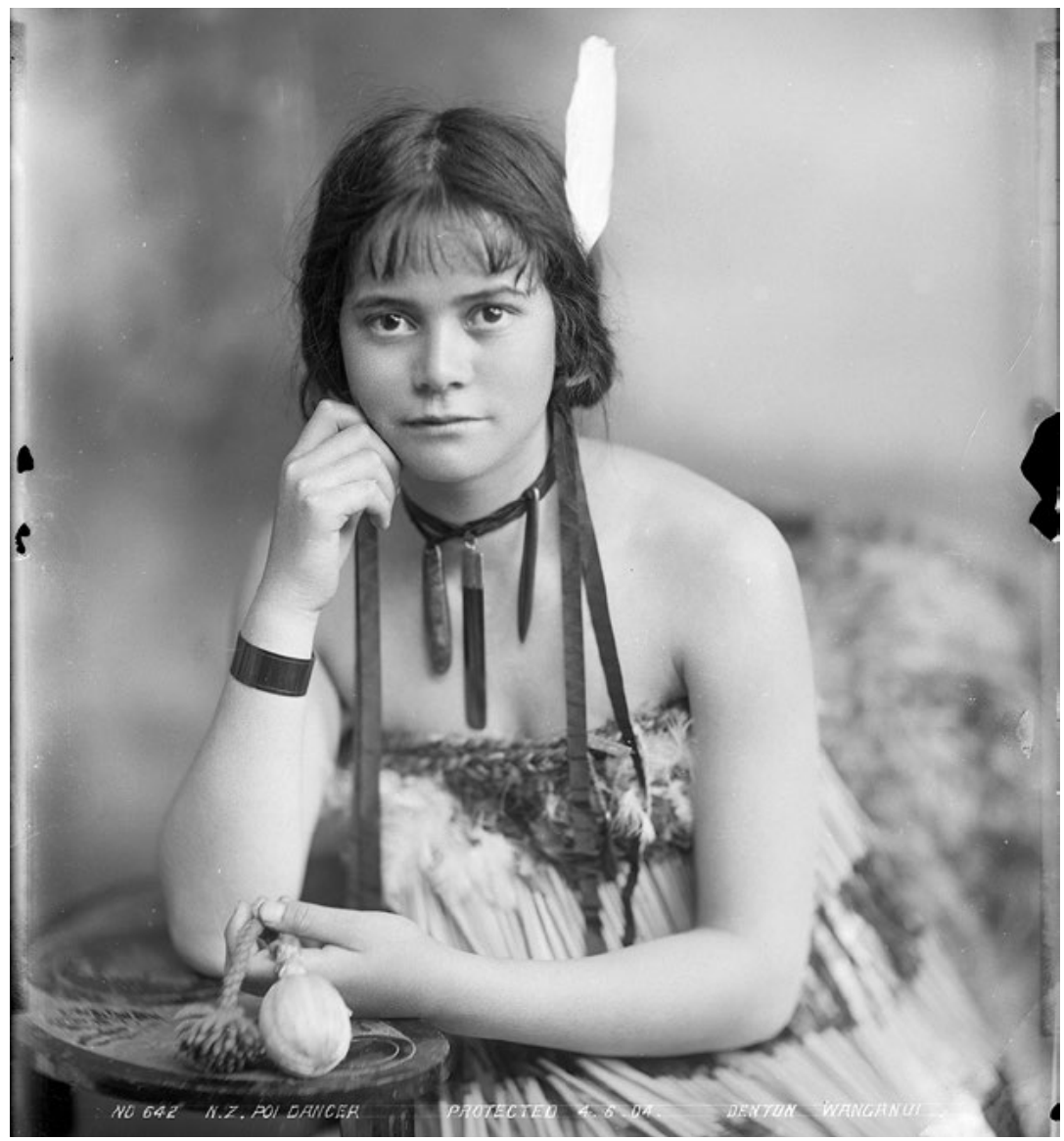

Figure 75. Young Māori woman wearing piupiu as 'traditional' Māori dress, early twentieth century.

Source. Young Māori woman with poi. Tesla Studios: Negatives of Wanganui and district taken by Alfred Martin, Frank Denton and Mark Lampe (Tesla Studios). Ref: 1/1-020797G. With permission, Alexander Turnbull Library, Wellington, New Zealand. Online: natlib. govt.nz/records/22492552 (accessed 23 May 2016). 
Tena koe Ta Hirini Mead,

Please allow me to republish this image from your invaluable book on Taniko. I note the helpful one and a half page reference to the pari in amongst your beautiful discussion of our taonga rongonui (well-known treasure) taniko weaving. I aim to build upon your work with a whole book on the subject of pari where the respectful acknowledgement you gave these women in the photo in your book continues in mine. Ma te wa, nga mihi nui matua.

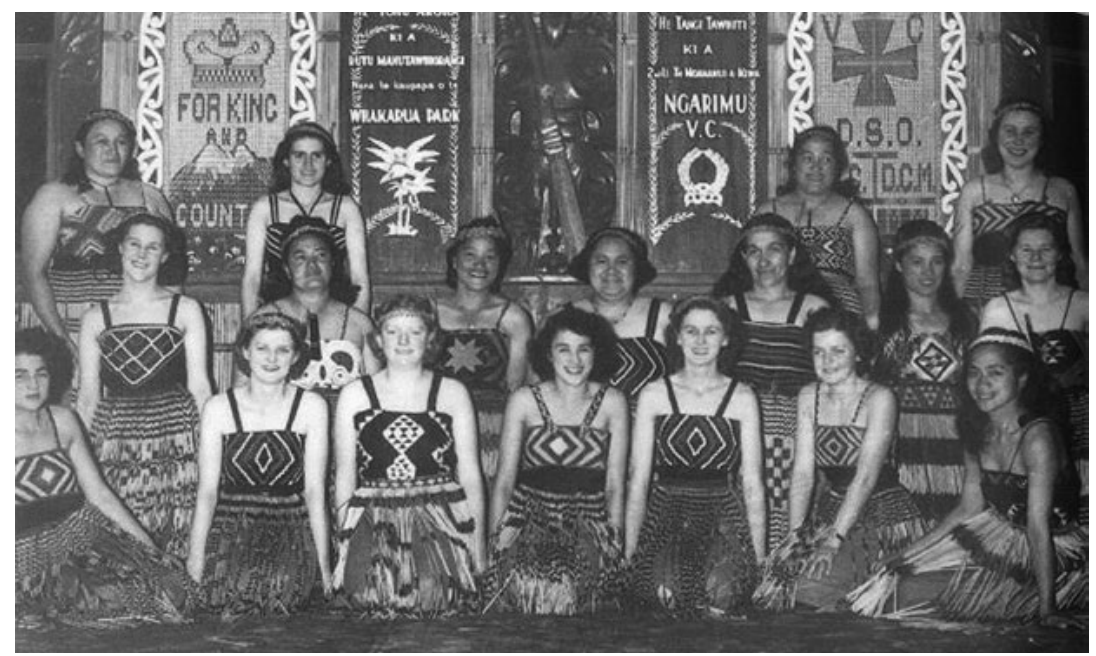

Figure 76. A variety of pari depicted in a monograph on the subject of taniko weaving. Performers from Ngati Porou of the East Coast of the North Island Aotearoa.

Source. Hirini Moko Mead, 1999, Te Whatu Taniko: Taniko Weaving Techniques and Tradition, Auckland: Reed, p. 12. Originally published in The Weekly News 1947. 


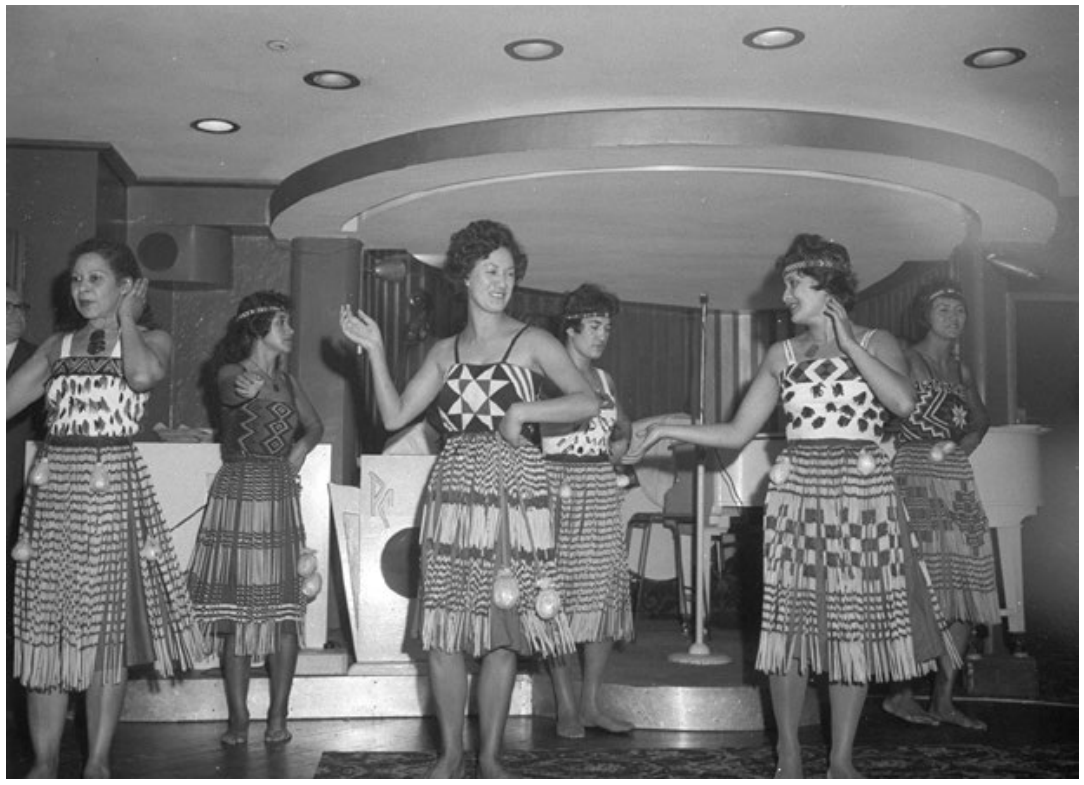

Figure 77. Unidentified Māori women in dance performance wearing a variety of pari. Pickwick Club, Sydney, 1962.

Source. Māori dancers at a cocktail party at the Pickwick Club to celebrate New Zealand Day 1962, digital order no. d7_12060. With permission State Library of New South Wales.

Dear Joan,

Sending you an image I picked up during my recent trip to Sydney and the Mitchell Library. I don't know anything yet about the Pickwick Club let alone these women who are wearing all kinds of pari-one for each individual. Why am I still surprised that I can't find anything published or archived about these women? Will try the club angle. ... Thanks so much for encouraging me to explore the subject further. Love Jo 
Dear Mum,

Sending you by email the photo we talked briefly about on the phone. Auntu Lottie most generously lent me the original when I last visited her. The pari you're wearing in the photo is unlike any l'd seen before but I am so pleased you recall it being made of kuta - a fibre I'm familiar with now, having woven with it for the past few months. Kuta is now mostly linked with the North, including Maraeroa near were Granpa [your father] was brought up, as you know. l'd love to know more about kuta's relationship with pari as well as Granpa. Since our phone call I found the other image in the Alexander Turnbull Library. As you can see its date is around the same time of your photo and has the only pari I know of that's similar to yours. I'll call you on the weekend to talk more about it. Do you know anyone in it? Love you, Jo

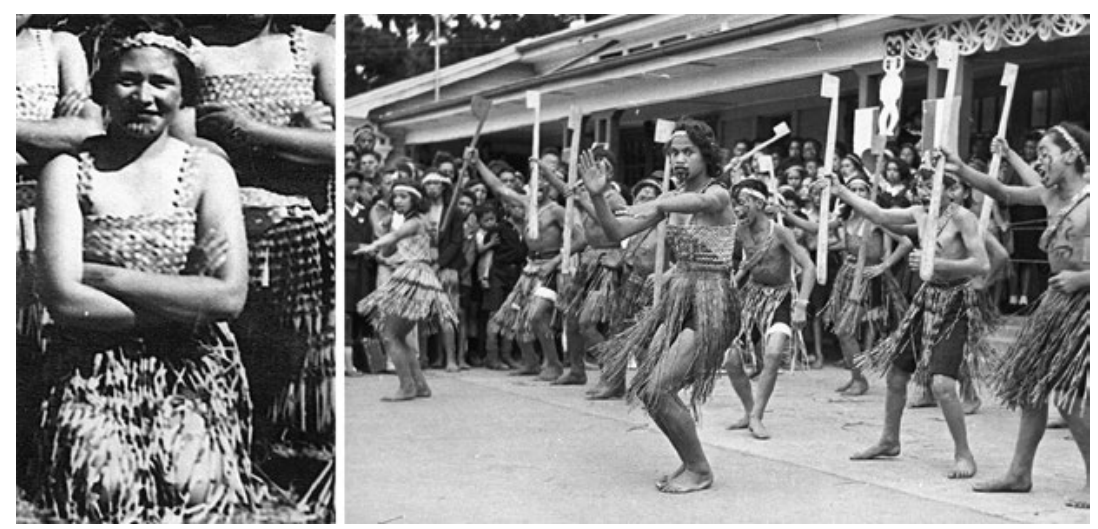

\section{Left: Figure 78. My mother the late Te Mihinga Eileen Diamond in her} early teens wearing a kuta pari.

Source. Photograph courtesy Tarati Waetford.

\section{Right: Figure 79. Kuta pari worn by children of a winning kapa haka team, Maraeroa, c. 16 April 1947.}

Source. New Zealand Free Lance. Photographic prints and negatives Studio De Luxe. Maori girls and boys of a winning haka team, Maraeroa. New Zealand Free Lance : Photographic prints and negatives. Ref: PAColl-6303-14. Alexander Turnbull Library, Wellington, New Zealand. Online: natlib.govt.nz/records/22607274 (accessed 23 June 2016). 
Kia ora cousin Jo,

Here's a picture of my pari designed by my mum and my Aunty Lottie in the late 1970s. Its reference to our homeland up north is mainly on the left though the black bordered part refer to nga hau e wha-my place is at home and in all four corners of the world, it says. We made this pari while I was at Waikato University; each of us in the kapa haka (culture group) had our own unique one and another black and gold uniform one. Both were made with needlepoint on purchased canvas. Maybe one day l'll transfer the red, black and white one's design into taniko. Thanks for reassuring me that its design is safe with you. I am thinking though of making a point about my mother's and your concerns regarding cultural property and protecting it from theft-of itself and its design. So, we struggle on towards justice and respect. Whawhai tonu ... Arohanui Jo

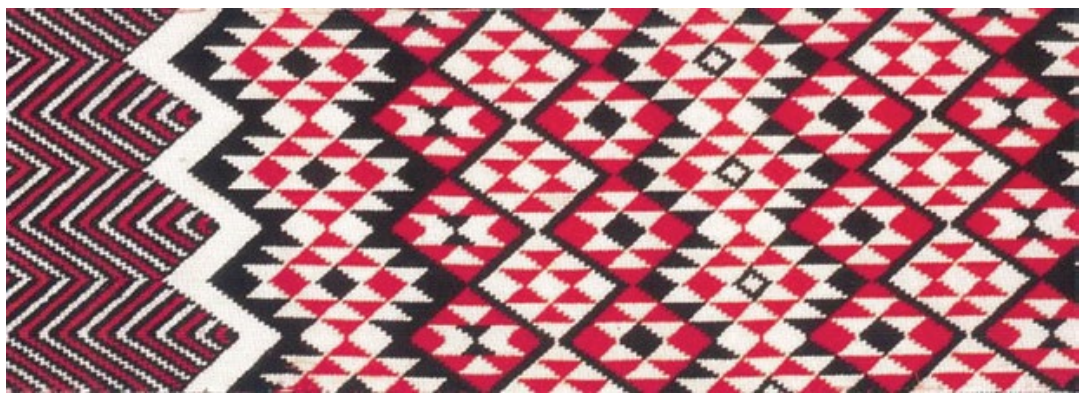

Figure 80. My pari made of wool cross-stitch designed by my mother Te Mihinga Eileen Diamond and her sister Tarati Waetford.

Source. Author's private collection.

Dear Nat,

Thank you for giving me permission to include this image of you in my thesis and book. The uniform of your group Te Rere o te Tarakakao of Canberra was first brought to my attention by my cousin Jo and has, to my knowledge, the only green and gold coloured pari anywhere in the world. Very appropriate for us Aussie Māori. All the best with your B. Enviro Science studies at Wollongong. Noho ora mai, Jo 
13. WRITING HOME ON THE PARI AND TOURING IN PACIFIC STUDIES

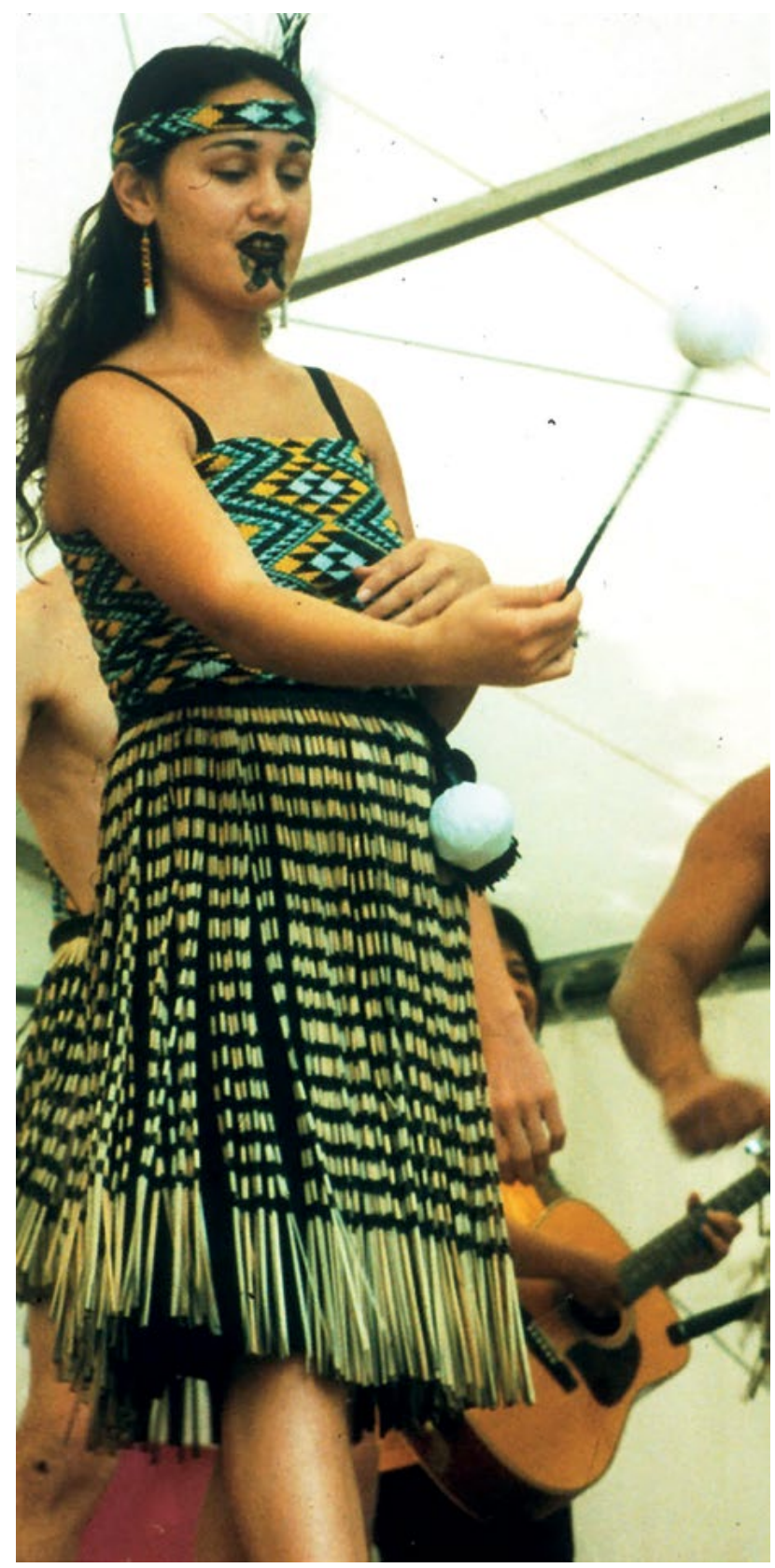

Figure 81. Nat Sullivan of Canberra-based Māori kapa haka, Te Rere o te Tarakakao wearing their distinctive green and gold pari based on Australian uniform colours.

Source. Reproduced from author's private collection and used with Nat Sullivan's permission. 
Journal Entry,

Was randomly wandering around the Opera House when I came across this show with brochure and obliging group of Te Kotuku performers included. Wowee what a pari! Need to contact them again for more details as they had to leave soon after I took the photo. Design looks over the top but the creativity afoot in Australia is amazing. I wonder about this innovation too as it seems to fly in the face of cultural correctness and conservatism required for tourism displays and some Mãori cultural groups here and back home in NZ.

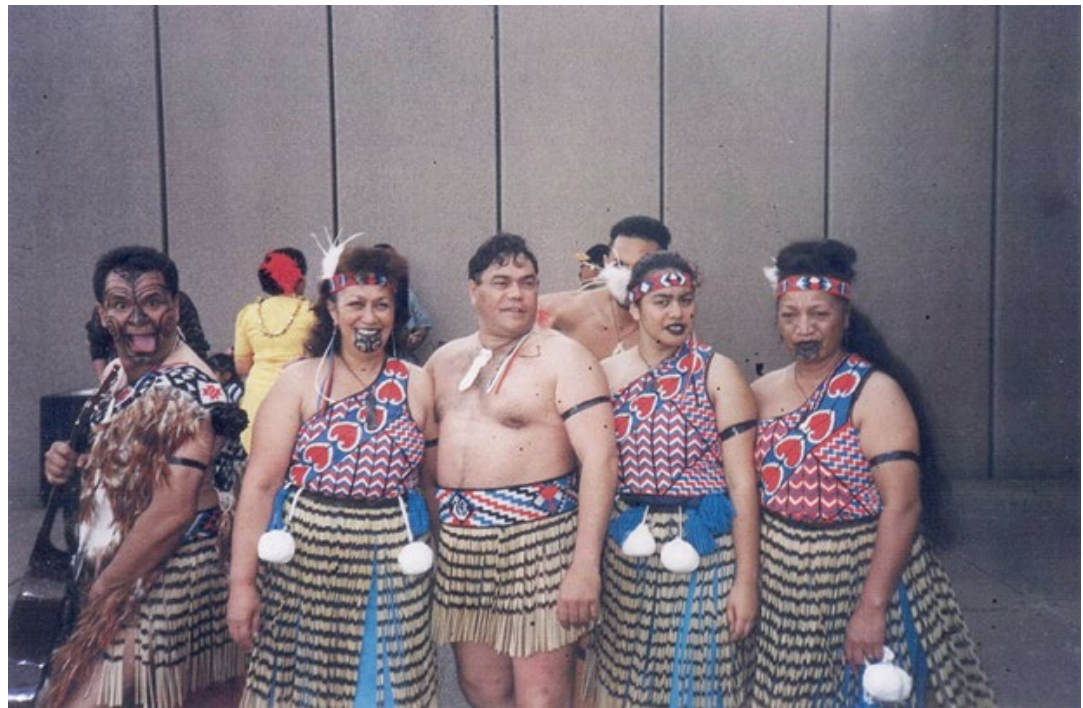

Figure 82. Members of Te Kotuku Māori kapa haka, Sydney, wearing their distinctive uniform, including pari.

Source. Photographed with permission by author. 


\section{Dear Margaret}

In reply to your enquiry, yes, my investigation continues into the history of the pari. I'm even more motivated by readily available images like those that appear on the internet with little description or analysis, including no identification of who the women are, let alone why and when their pari came about. In these images there is so much variety, including a colourful departure from usual designs and an extraordinary diversity of materials. 'What do they mean?' is still a constant question and apart from my dear, concerned mother who once cautioned me that some people may find the subject of pari tapu (sacred) due to its proximity to breasts and mute it accordingly, many people are impressed by my curiosity and willing to help. With best regards and appreciation, Jo

Tena koutou o te ropu Hakahula, nga mihi mahana ... I am currently writing a book about pari and was delighted to find your photo online. I wish to come and talk with you about your uniform. Please let me know if and when that's possible. Heoi ano, naku noa na, Jo Diamond

\section{Dear Roseanna}

I'm so glad we're Facebook friends. Thanks for your skype details. It's certainly more economical talk to you that way especially about 'Ngati Ranana' and your distinctive pari. I hope to come to London soon though the uni here is facing huge financial struggles post-earthquakes. So I'll catch you on skype. Looking forward to learning about your pari-where it came from and where it might go along with the women who wear it so well over there on the other side of the world. Ma te aroha me te matauranga matou e manaaki, Jo

\section{Dear Ambassador,}

Further to my earlier letter, thank you for your kind willingness to participate in discussions with me and the 'Māori Manaia' group members regarding the World Tour last year (2011), their striking uniform, including the pari. As I arrive in London the day before, I see no problem in finding the venue for our scheduled meeting next month. Thank you for your concern and I look forward to meeting you in person. Very best regards, Jo 


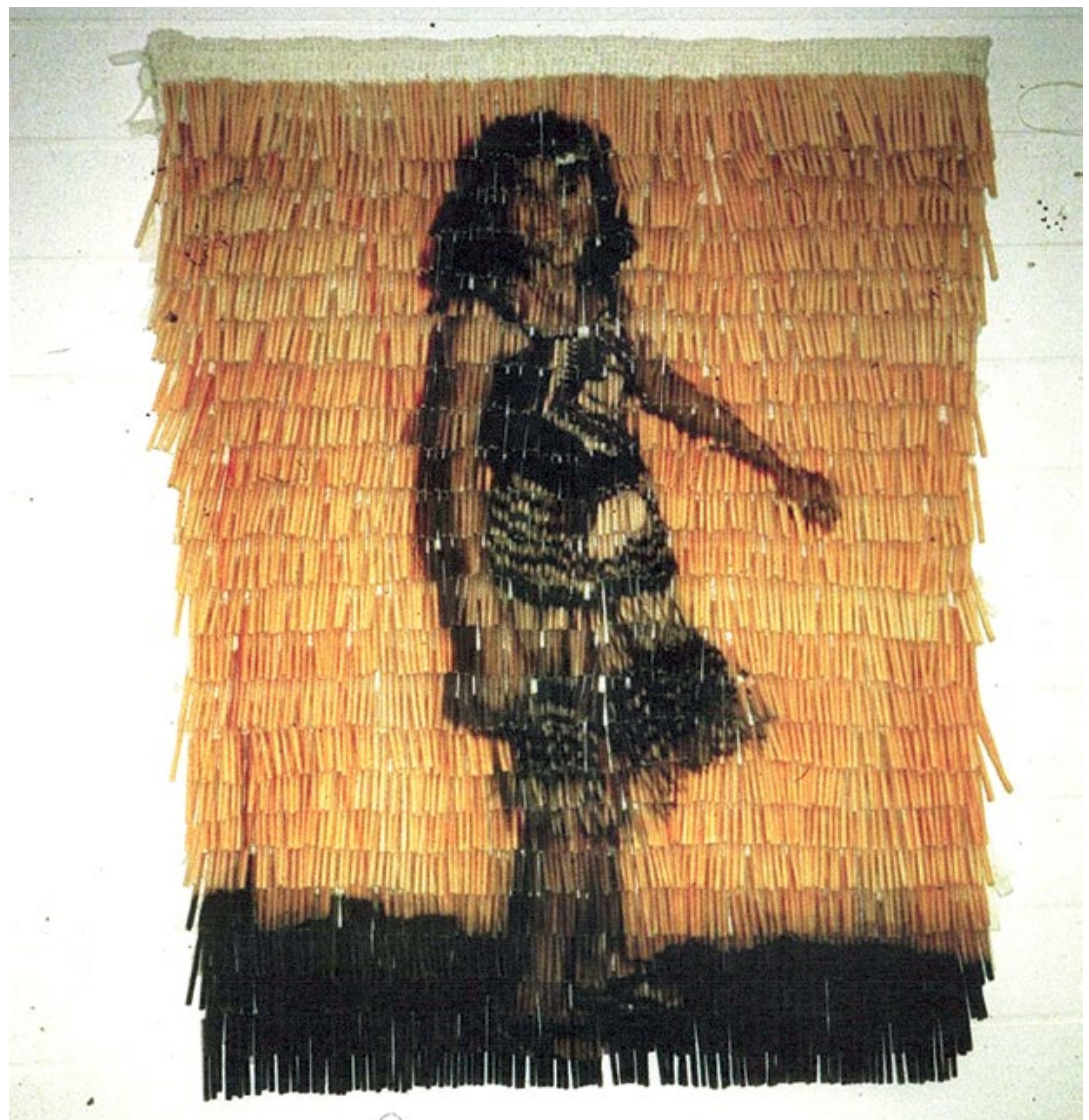

Figure 83. Keren Ruki, 1999, Māori girl (a kākahu) 120 x 90 cm. Cotton, tape, cane, iron-on transfers.

Source. Photograph, courtesy of the artist.

E te wahine toa, my dear friend Keren,

The world has come full-circle for me and the pari and now I seek your permission once again to use this image for my book and exhibition. I know you appreciate that your self-portrait's pari is a significant expression of Māori identity and please know, if you don't already, that I've always respected the various layers of cultural meaning you address in your work. I'm assured that we are both in the business of commenting upon and bringing to light the richness of Māori experience, including those features not published or exhibited publicly except on our marae and in staged festivals and concerts. I look forward to our continued conversation on these and many other matters. An official invitation to the book launch and exhibition is on its way. Aroha pumau tonu, Jo 
One more snippet.

So much remains to be said, written, sang and danced within the 'field' of pari and the wider 'field' of Pacific Studies. I am likely to continue critical analyses based on feminist and post-colonial discourses, those dominant and those marginalised. Not intending definitive conclusion, but offering a robust and substantial basis for critical engagement with pari, my work progresses. This endeavour has been and continues to be a tour of touring pari that finds comparison, if not equivalence with other Pacific items of clothing and the people of the past, present and future that design, make and wear them. That tour, this tour has begun ...

\section{References}

Alexander Turnbull Library Photographic Collection. Online: natlib. govt.nz/collections/a-z/photographic-archive (accessed 25 February 2016).

Bigwood, Kenneth and Jean Bigwood. 1970. New Zealand in Pictures: The Māoris: A Selection of Colour Plates. Auckland and Wellington: A.H. and A.W. Reed.

Diamond, Jo. 2004. 'Revaluing Raranga: Weaving and women in TransTasman Māori cultural discourses.' PhD thesis, The Australian National University.

Diamond, Jo. 2014. 'Pari: Narratives of a Māori bodice.' Unpublished manuscript.

Hall, C. Michael. 2011. 'Fieldwork in tourism/touring fields: Where does tourism end and fieldwork begin.' In Fieldwork in Tourism: Methods, Issues and Reflections, ed. C. Michael Hall, pp. 7-18. Oxon, Routledge.

Hall, C. Michael (ed.). 2011. 'Fieldwork in Tourism: Methods, Issues and Reflections. Oxon, Routledge.

Mead, Hirini Moko. 1999. Te Whatu Taniko: Taniko Weaving Techniques and Tradition. Auckland: Reed. 
This text is taken from Touring Pacific Cultures, edited by Kalissa Alexeyeff and John Taylor, published 2016 by ANU Press, The Australian National University, Canberra, Australia. 